Article

\title{
Business Ethics as a Sustainability Challenge: Higher Education Implications
}

\author{
Guillermina Tormo-Carbó ${ }^{1, *}$, Elies Seguí-Mas ${ }^{1 \text { (I) }}$ and Víctor Oltra ${ }^{2}$ \\ 1 CEGEA, Centre for Research in Business Management, Universitat Politècnica de València, 46022 Valencia, \\ Spain; esegui@cegea.upv.es \\ 2 Department of Business Management, Facultat d'Economia, University of Valencia, 46022 Valencia, Spain; \\ victor.oltra@uv.es \\ * Correspondence: gtormo@omp.upv.es; Tel.: +34-96-387-7686
}

Received: 30 June 2018; Accepted: 30 July 2018; Published: 2 August 2018

\begin{abstract}
Recent financial scandals worldwide have intensified concern for business (and especially accounting) ethics. Hence, under an overall economic and social sustainability approach, it is crucial to improve the effectiveness of business ethics and corporate social responsibility (CSR) education, in terms of its impact on business students' awareness of ethical issues. However, stand-alone business ethics/CSR courses are uncommon in Spanish universities. Accordingly, this paper aims at examining the influence of ethics courses on students' awareness of business ethics in unfriendly environments. We test our hypotheses, through hierarchical regression, in a sample of 551 management students of a Spanish university. Our results suggest that business ethics/CSR courses increase awareness of the importance of ethics in: (i) business courses, (ii) recognizing accounting ethical implications, and (iii) workplace decisions. Our findings also show that a joint interactive effect of gender (female students) and age (older students) increases the impact of business ethics/CSR courses on students' awareness of the importance of: (i) ethics in workplace decisions, and (ii) the recognition of accounting ethical implications. Our results also support the relevance of different learning styles and the convenience of adapting ethics/CSR teaching methods depending on students' characteristics. Research and practical implications are derived from our findings.
\end{abstract}

Keywords: business; corporate social responsibility; ethics; education; student's perceptions; sustainability

\section{Introduction}

The necessity of balancing economic growth with social and environmental concerns, thereby reinforcing the relevance of the idea of sustainable development, is gaining interest [1]. At a corporate level, sustainable development carries significant implications, insofar companies play a key role in the long-term synergistic achievement of the so-called triple (economic, social and environmental) bottom line of socially-responsible corporate behaviour and performance [2,3].

In this context of the relevance of corporate social responsibility (CSR) and sustainability issues in business, ethical decision-making becomes crucial for sustainable accomplishment of (corporate and social level) triple bottom line goals $[4,5]$. As a part of this overall picture-whereby business ethics, CSR and sustainability concerns, concepts and frameworks overlap significantly-a specific issue that is receiving growing attention from academics' and practitioners' alike is the relevance of ethical practice in accounting [6], which—in line with our above arguments-should be indeed framed under a broader sustainability perspective.

Consistent with these concerns, interest is growing regarding the need to enhance education on business ethics [7-14]. Although standards and regulatory norms can contribute to reducing 
the risks of accounting malpractice, the most effective way to achieve this goal would be to boost accountants' capabilities to consider ethical issues and act accordingly $[15,16]$. In this sense, ethical and socially responsible behaviour shown by forthcoming professionals is being currently shaped by higher education curricula [2,17-19]. In the context of convergence towards the Higher Education European Area, key generic competences significantly influence the education of future graduates. Among these competences, professional and ethical responsibility is gaining relevance $[13,19,20]$. In other words, education transmits a set of values that can significantly shape students' future professional development, in turn building an ethically-grounded perception of business and social responsibilities $[2,17,17,20]$. Accordingly, business ethics and Corporate Social Responsibility (CSR) in higher education can crucially influence the future of the accounting profession [21]. In this context, it is important to note that business is one of the most popular majors chosen by Spanish university students [22] A management degree is also one of the three most valued profiles required in the labour market [23].

However, competencies in CRS or business ethics are, still, not considered essential for Business Administration and Management degrees in public Spanish universities. Only 18\% of Spanish universities include stand-alone CRS or business ethics subjects in their curriculum. In addition, public universities offer these courses as optional subjects [24], often including terms such as business ethics, CSR or sustainability rather interchangeably in the course names, consistent with their significant conceptual and overlapping [25]. Specifically, the students enrolled in the Bachelor's in Management at the Technical University of Valencia can attend an elective course called "Ethics and Corporate Social Responsibility". There are no more courses (mandatory or elective) related to business ethics, CSR, or sustainability issues.

Understanding ethical behaviour from a legalistic-contractarian point of view (cf. [26]), we assume that those contexts where adherence to (business/accounting) law and respect for contracts is widespread are ethics-friendly environments. Conversely, if law-inobservance is relatively common, usually in connection with high corruption levels, we consider it to be facing an ethics-unfriendly environment (cf. [14]). Spain has recently witnessed a number of financial malpractice cases [27], often closely related to corruption scandals [28]. These facts, together with the increasing importance of ethical reporting in Spain [29], the popularity of business degrees, and the increasing relevance of ethics/CSR courses at Spanish universities [9], identify this country as a highly appropriate setting for our investigation.

The extent of success in the development of business ethics/CSR courses in higher education [30] can crucially determine the evolution of the accounting profession [15]. Accordingly, the risk of financial malpractice can be considerably minimized if ethical awareness among employees is an attitude expected by financial sector companies and, as such, foreseeable from job applicants [31]. Considering that the main goal of business/accounting ethics teaching is to improve ethical behaviour of future management/accounting professionals, and keeping in mind the inconclusiveness of inquiry to date, it seems highly relevant to study how management students react to business ethics teaching [13].

Waples el al. [32] identified several course characteristics-including traits of participants, quality of instruction, instructional content, general programme characteristics, and instructional methods-which may influence ethics course effectiveness. Teaching methods, reviews of prior content, essays, large group discussions, lectures, and readings have shown negative links with ethics/CSR instruction effectiveness. However, debates, computer-based simulations, web-based discussions, self-reflection activities, role playing, and small-group discussions have shown a positive association with ethics/CSR instruction effectiveness [33]. In addition, using active learning strategies when teaching ethics/CSR courses will improve the student's learning experience [34] and, subsequently, enhance students' ethical awareness.

This article offers the novelty of exploring - under a broader (economic and social) sustainability perspective-further explanations and directions to increase the understanding of the influence 
of business ethics teaching on students' ethical awareness, by considering the moderating effect of gender and age. By ethical awareness we understand the extent to which students perceive a number of general and accounting ethics aspects as important. In turn, such aspects indicate the effectiveness-if applicable — of ethics/CSR courses taken by students, in terms of ethics/CSR courses' potential to shape future professional behaviour from an ethical point of view. We hypothesize and test the model represented in Figure 1. Our investigation advances towards new directions by deepening into how gender and age interact with business ethics courses.

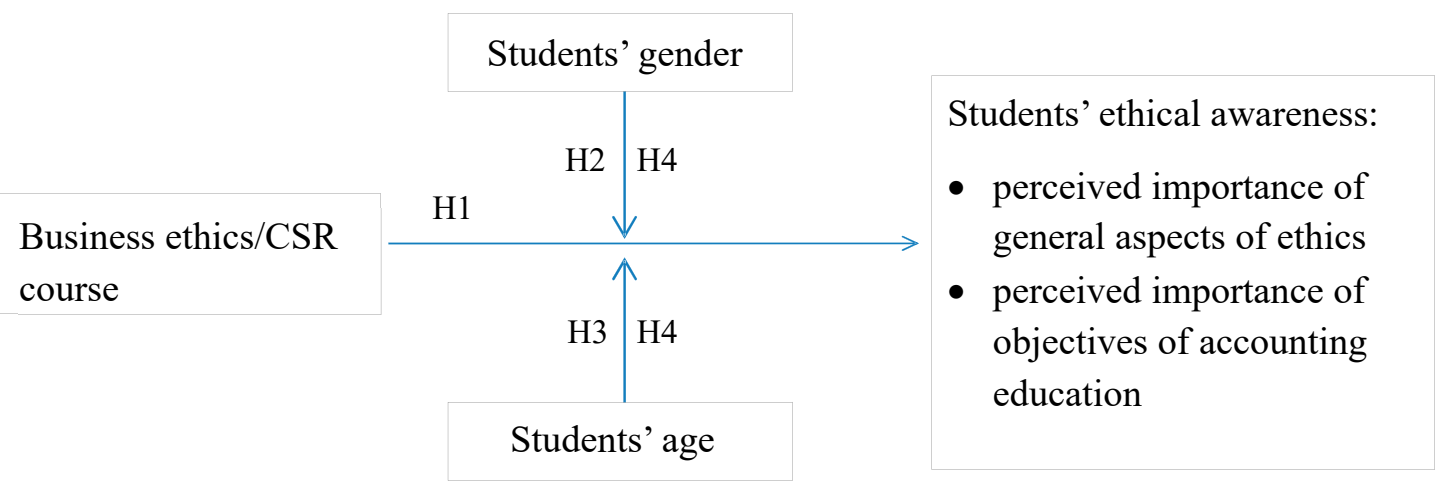

Figure 1. Research model.

As a result, we pose two research questions:

- In ethics-unfriendly environments, do ethics/CSR courses increase business students' ethical awareness, in terms of their perceived importance of (i) general aspects of ethics and (ii) objectives of accounting education?

- In ethics-unfriendly environments, do gender and age of business students moderate the impact of ethics/CSR courses on business students' ethical awareness, in terms of their perceived importance of (i) general aspects of ethics and (ii) objectives of accounting education?

Following this introduction, the next section of this article includes a literature review and introduces our hypotheses. The subsequent section of the paper outlines the research methods, and the fourth section reports the results of the study. The fifth section of the paper includes a discussion of the study outcomes, and the paper finishes with a conclusion.

\section{Literature Review and Hypotheses}

\subsection{Business Ethics and CSR Courses, Business Ethics Education Effectiveness, and Business Students' Ethical Awareness}

Research has so far illustrated that management students deem ethics courses as relevant $[14,31,32,35]$. The importance of considering the perspectives of three communities involved-scholars, accounting professionals, and students-has been highlighted [36]. However, worries and uncertainties arise about the possible ineffectiveness of present accounting and management university courses in boosting students' ethical awareness [37]. Hence, it is important to assess the extent to which business ethics/CSR courses are effective, that is, are actually increasing students' ethical awareness-as a way to predict ethically-minded future professional behaviour.

Outcomes of enquiry on the impact of ethics teaching on ethical awareness or behaviour are rather inconclusive [38]. Low et al.'s [39] study could not definitely prove that students' perceptions of ethics teaching had a significant impact on their ethical behaviour. Even so, students assumed that it was relevant to include ethics/CSR courses in their curricula [39]. Likewise, Dearman and Beard [40] pinpointed that participants' ethical-oriented behaviours during experiments did not necessarily imply that they would show similar behaviours when facing actual circumstances. Hence, substantial 
accounting and economics investigations seem to neglect the incentives that participants may have to develop opportunistic (unethical) behaviour when acting in non-experimental contexts [40]. Besides, Waples et al. [32] developed a meta-analysis on 25 business ethics educational programmes, finding just a marginal influence from them on improving ethical awareness, perceptions, or behaviour. In this sense, it is argued that that ethics/CSR courses are often too abstract, thus failing to influence strongly enough management students' ethical awareness and behaviour [41,42].

However, Nguyen et al. [43] found out that ethics learning significantly predicted ethical behavioural intent. Although this is an insightful outcome, it must be taken with caution, since intentions and behaviour are often quite apart in the context of business ethics [8]. Precisely, our study is based on behaviours, since we regard the action of taking a business ethics/CSR course as an explicit and tangible manifestation of the students' interest in business ethics. In this sense, we suppose that the decision of enrolling into an elective ethics/CSR course is derived from a personal interest in such field. In this study, we substantially understand business ethics/CSR course effectiveness as the extent to which such courses impact students' ethical awareness. We assume that the fact of voluntarily taking an ethics/CSR course is a behavioural indicator and, as such, should predict the way students perceive the importance of (business) ethical issues in general and in accounting in particular. Hence, our first hypothesis is stated as follows:

Hypothesis 1 (H1). Exposure to business ethics/CSR courses positively influences business students' ethical awareness, in terms of a greater perception of the importance of a number of (i) general aspects of ethics and (ii) objectives of accounting ethics education.

\subsection{The Moderating Effect of Business Students' Gender and Age on the Effectiveness of Business Ethics Education}

Socially construed roles and stereotypes influence expectations on the behaviours of men and women [44,45]. Men are expected to focus on assertion, ambition and competition, and by developing these traits and goals, they are more prone to showing unethical behaviours than women. Conversely, women are generally more concerned about harmony, warmth, altruistic values, and caring for others' well-being [46]. After over 35 years of inquiry, empirical findings on how ethical decision-making is influenced by gender are rather inconclusive [47]. The reviews by $\mathrm{O}^{\prime}$ Fallon \& Butterfield [41] and Craft [48] found a high diversity of results, although the most common significant outcomes were those indicating that women presented a higher ethical awareness than men.

In any case, despite the existence of inconclusive results [49], empirical research on the connection between business students' gender and ethical awareness increasingly supports the above ideas. A number of studies have shown a higher ethical awareness among female students compared to male ones (e.g., $[47,50,51])$. Importantly, these outcomes have been corroborated in research based on business students [14,32]. Accordingly, a starting point of our investigation is the assumption that female students show a higher ethical awareness than male students.

The combination between H1 (positive effect of business ethics/CSR courses on students' ethical awareness) and the above gender-related assumptions lead us to argue for a synergistic interaction between taking an ethics/CSR course and being female on the effectiveness of the business course taken. Although scarce, there are some studies involving different aspects of this interaction. Assuming that female students are more (naturally) ethically aware than male ones, taking ethics courses has been shown to increase (otherwise naturally lower) male students' ethical awareness [52]. In another study, women in an experimental class (exposed to a curriculum with an increased ethics contents) showed significantly improved ethical awareness [42]. This supports a synergistic effect of ethics teaching and gender, which is consistent with our argumentation. Hence, we propose our second hypothesis: 
Hypothesis 2 (H2). The positive influence of the exposure to business ethics/CSR courses on business students' ethical awareness, in terms of a greater perception of the importance of a number of (i) general aspects of ethics and (ii) objectives of accounting ethics education, is positively moderated by the fact of being a female student.

Regarding the age of individuals, it is traditionally assumed that ethical consciousness increases with age [53]. In his sense, there seems to be widespread agreement on the belief that age increases the personal consideration of higher ethical standards, a fact that in turn heightens intolerance of ethical shortcomings [46]. Regarding empirical evidence, there are inconclusive results [50]. There are findings showing that stronger ethical viewpoints are associated to youth [54]. However, most research has found that ethical awareness increases with age $[55,56]$. Moreover, and similar to what happened with gender (female vs. male), research has also evidenced that older business students show a higher ethical awareness than younger ones [32]. Consequently, we assume, as a starting point in our research, that age is positively related to ethical awareness of business students. Accordingly, the combination between H1 (positive effect of business ethics/CSR courses of students' ethical awareness) and the above age-related assumption, lead us to argue for a synergistic interaction between taking an ethics/CSR course and being older on the effectiveness of the business course taken. As a result, we formulate our third hypothesis:

Hypothesis 3 (H3). The positive influence of exposure to business ethics/CSR courses on business students' ethical awareness, in terms of a greater perception of the importance of a number of (i) general aspects of ethics and (ii) objectives of accounting ethics education, is positively moderated by the fact of being an older student.

Furthermore, we believe that it is also worthwhile to explore a possible joint double moderation between gender and age on the effectiveness of ethics/CSR courses. In this regard, extant research has evidenced gender as a moderator in the relation between age and ethical awareness. Specifically, Peterson et al. [56] tested ethical awareness across two age groups: women showed higher ethical awareness in the younger group, whereas men did so in the older group. The latter result suggests that age can counter-balance the effects of gender in the case of older people. Indeed, in contexts where external factors may influence ethical awareness, Peterson et al. [56] observed a significant interaction between age and gender. These outcomes seem to render support to a triple interaction between ethics/CSR courses (as a non-demographic external factor), age, and gender. Consequently, we propose our fourth hypothesis:

Hypothesis 4 (H4). The positive influence of the exposure to business ethics/CSR courses on business students' ethical awareness, in terms of a greater perception of the importance of a number of (i) general aspects of ethics and (ii) objectives of accounting ethics education, is positively moderated by the facts of being both a female and an older student.

\section{Methodology}

We conducted a survey of a population of 1,825 management students at the Technical University of Valencia. The sample is made up of management students who are or were enrolled in accounting courses. There are accounting courses every year in the Bachelor's Degree in Management at the Technical University of Valencia (starting with a compulsory course in the first year). This degree is strongly focused on two specializations (depending on elective courses): Accounting and Finance and Management. In any case, nine out of the thirty compulsory courses of this degree belong to the Accounting and Finance field. Therefore, all students of the Bachelor's of Management at the target university must take several compulsory courses related to accounting.

Students voluntarily responded to the questionnaire during regular class hours for a variety of courses. All respondents were officially enrolled as (undergraduate) management students. Respondents might differ on their current year of studies, specializations and elective courses, and-particularly—on having (or not) taken a course on business ethics—although the overall 
sample homogeneity helps strengthen the validity of the results. The response rate was $30.19 \%$ (551 questionnaires were returned properly completed). Sample characteristics are illustrated in Table 1.

Table 1. Sample characteristics.

\begin{tabular}{cc}
\hline & $n=551$ \\
\hline Sex & \\
\hline Female & 339 \\
Male & 209 \\
No response & 3 \\
\hline Nationality & \\
\hline Spanish & 479 \\
Other & 72 \\
\hline Ethics/CSR courses taken & \\
\hline Yes & 166 \\
No & 399 \\
Not sure & 36 \\
\hline
\end{tabular}

The questionnaire items used in this investigation can be grouped into three main sections (see Appendix A). The first section gathered demographic data and asked whether students had already taken ethics/CSR courses. Ethics/CSR course and gender are dichotomic variables (no ethics $/$ CSR course $=-1$, ethics $/$ CSR course $=+1$; male $=-1$, female $=+1$ ). Age is a continuous variable. Ethics/CSR course is the independent variable in all hypotheses. Gender and age are the moderating variables in, respectively, $\mathrm{H} 2$ and $\mathrm{H} 3$. Both gender and age are co-moderating variables in $\mathrm{H} 4$.

In the second section of the questionnaire, students rated their perceived importance of ethics in four General Aspects of Ethics (GAE). In the third section, students evaluated their perceived importance of seven Objectives of Accounting ethics Education (OAE). Both GAE and OAE sets of items comprise the study dependent variable, namely business student's ethical awareness. The second and third questionnaire sections were adapted from Adkins and Radtke's scale [32]. That scale was based on earlier proposals by Callahan [57] and Loeb [10], and has been also used in other studies on accounting ethics education (e.g., [14,31,58]). A seven-point Likert scale was used in the second and third sections, from a rating of 1 meaning "important" to a rating of 7 meaning "unimportant".

\section{Results}

Table 2 presents the main descriptive statistics of the sample and the correlations between all variables. Hypotheses have been tested through multivariate analysis. Given the focus of our model on moderated (i.e., interactive) effects between variables, we decided to apply hierarchical regressions as an appropriate analysis technique [59].

In the first step, the direct effect of ethics/CSR course on students' ethical awareness (both GAE and $\mathrm{OAE}$ aspects) was assessed (H1). In the second step, we tested the relation between gender and age and students' ethical awareness (relations which we did not hypothesize but took for granted according to prior literature). The third step assessed two two-way interactive effects: first, the interaction between ethics/CSR course and gender on students' ethical awareness (H2); second, the interaction between ethics/CSR course and age on students' ethical awareness (H3). Finally, in the fourth step, we evaluated a three-way interaction among the ethics/CSR course, gender and age on students' ethical awareness (H4). Following Cohen et al.'s [60] suggestions, we used mean-centred ratings so as to reduce multi-collinearity effects. Non-standardized coefficients were also used, since standardized ones are affected by the mean-centring and are difficult to interpret in interaction analyses. Tables 3 and 4 report the hierarchical regression analyses conducted regarding GAE (Table 3) and OAE (Table 4). 
Table 2. Descriptive statistics and correlations.

\begin{tabular}{|c|c|c|c|c|c|c|c|c|c|c|c|c|c|c|c|c|}
\hline Variables & Mean & $S D$ & GAE1 & GAE2 & GAE3 & GAE4 & OAE1 & OAE2 & OAE3 & OAE4 & OAE5 & OAE6 & OAE7 & E.C. & G. & A. \\
\hline GAE1. Ethics in business community & 2.57 & 1.40 & & & & & & & & & & & & & & \\
\hline $\begin{array}{l}\text { GAE2. Ethics in business courses } \\
\text { Ges }\end{array}$ & 2.50 & 1.30 & $0.762 * *$ & & & & & & & & & & & & & \\
\hline GAE3. Ethics in pers. decisions & 2.08 & 1.21 & 0.513 ** & $0.535^{* *}$ & & & & & & & & & & & & \\
\hline GAE4. Ethics in workplace decis. & 2.37 & 1.27 & 0.517 ** & 0.580 ** & $0.683 * *$ & & & & & & & & & & & \\
\hline OAE1. Relating AE to moral issues & 3.33 & 1.44 & $0.295 * *$ & 0.357 ** & 0.257 ** & $0.307 * *$ & & & & & & & & & & \\
\hline $\begin{array}{l}\text { OAE2. Recognizing ethical implications of } \\
\text { accounting issues }\end{array}$ & 3.05 & 1.33 & $0.333 * *$ & $0.422 * *$ & $0.309^{* *}$ & $0.360 * *$ & $0.660 * *$ & & & & & & & & & \\
\hline OAE3. Developing "a sense of moral obligation" & 2.59 & 1.31 & $0.371^{* *}$ & $0.443 * *$ & $0.440 * *$ & $0.470 * *$ & 0.503 ** & $0.556 * *$ & & & & & & & & \\
\hline OAE4. Developing conflict-tackling abilities & 2.52 & 1.30 & 0.401 ** & 0.468 ** & $0.439 * *$ & 0.436 ** & 0.431 ** & 0.505 ** & $0.631^{* *}$ & & & & & & & \\
\hline OAE5. Learning to deal with uncertainties & 2.52 & 1.23 & 0.346 ** & 0.413 ** & $0.422 * *$ & 0.364 ** & 0.329 ** & $0.392 * *$ & 0.507 ** & $0.609 * *$ & & & & & & \\
\hline OAE6. Fostering change in ethical behaviour & 2.99 & 1.28 & $0.383 * *$ & $0.469^{* *}$ & $0.367^{* *}$ & 0.450 ** & 0.476 ** & 0.480 ** & $0.538 * *$ & $0.572 * *$ & 0.471 ** & & & & & \\
\hline OAE7. Understanding ethical aspects & 3.37 & 1.40 & 0.320 ** & $0.367 * *$ & $0.285 * *$ & 0.327 ** & 0.471 ** & 0.438 ** & $0.441 * *$ & 0.440 ** & 0.353 ** & $0.584 * *$ & & & & \\
\hline Ethics Courses & $\begin{array}{l}.307 \\
-0.57\end{array}$ & 0.823 & -0.062 & $-0.093 *$ & -0.058 & $-0.124 * *$ & -0.084 * & -0.053 & -0.045 & -0.071 & 0.002 & $-0.127 * *$ & -0.002 & & & \\
\hline Gender & 0.24 & 0.972 & $-0.162^{* *}$ & $-0.160 * *$ & $-0.155^{* *}$ & $-0.203^{* *}$ & $-0.089 *$ & $-0.147^{* *}$ & -0.139 ** & -0.172 ** & -0.142 ** & $-0.237 * *$ & $-0.157^{* *}$ & 0.035 & & \\
\hline Age & 21.23 & 3.58 & -0.065 & $-0.106 *$ & $-0.090 *$ & $-0.138 * *$ & $-0.156 * *$ & $-0.165 * *$ & $-0.113 *$ & $-0.097^{*}$ & -0.056 & $-0.199 * *$ & $-0.104 *$ & $0.165^{* *}$ & $-0.095 *$ & \\
\hline
\end{tabular}

Table 3. Hierarchical regression for general aspects of ethics.

\begin{tabular}{|c|c|c|c|c|c|c|}
\hline \multirow[b]{2}{*}{ Independent/Moderating Variables } & \multirow{2}{*}{$\begin{array}{c}\text { Step1 } \\
\text { Ethics/CSR Course }\end{array}$} & \multicolumn{2}{|c|}{ Step2 } & \multicolumn{2}{|c|}{ Step 3} & \multirow{2}{*}{$\frac{\text { Step } 4}{\text { Course }^{*} \text { Gender }{ }^{*} \text { Age }}$} \\
\hline & & Gender & Age & Course * Gender & Course * Age & \\
\hline \multicolumn{7}{|l|}{ Dep. variable (items of GAE) } \\
\hline \multicolumn{7}{|c|}{ GAE1. Ethics in business community $(n=464)$} \\
\hline B & -0.095 & -0.220 ** & -0.029 & -0.046 & -0.004 & -0.004 \\
\hline SBE & 0.075 & 0.064 & 0.018 & 0.078 & 0.027 & 0.018 \\
\hline R2 & 0.003 & \multirow{2}{*}{\multicolumn{2}{|c|}{$\begin{array}{c}0.029 \\
5.032 \text { ** }\end{array}$}} & \multicolumn{2}{|c|}{0.03} & 0.03 \\
\hline $\mathrm{F}$ & 1.593 & & & \multicolumn{2}{|c|}{$3.079 * *$} & $2.571 *$ \\
\hline \multicolumn{7}{|l|}{ GAE2. Ethics in business courses $(n=463)$} \\
\hline B & -0.150 * & $-0.206^{* *}$ & $-0.040 *$ & -0.034 & -0.037 & -0.013 \\
\hline SBE & 0.070 & 0.059 & 0.016 & 0.072 & 0.025 & 0.016 \\
\hline R2 & 0.009 & \multirow{2}{*}{\multicolumn{2}{|c|}{0.041}} & \multicolumn{2}{|c|}{0.045} & 0.046 \\
\hline $\mathrm{F}$ & 4.578 * & & $7.022 * *$ & \multicolumn{2}{|c|}{4.661 ** } & $3.981 * *$ \\
\hline
\end{tabular}


Table 3. Cont

\begin{tabular}{|c|c|c|c|c|c|c|}
\hline \multirow[b]{2}{*}{ Independent/Moderating Variables } & \multirow{2}{*}{$\begin{array}{c}\text { Step1 } \\
\text { Ethics/CSR Course }\end{array}$} & \multicolumn{2}{|c|}{ Step2 } & \multicolumn{2}{|c|}{ Step 3} & \multirow{2}{*}{$\frac{\text { Step } 4}{\text { Course }^{*} \text { Gender } * \text { Age }}$} \\
\hline & & Gender & Age & Course * Gender & Course * Age & \\
\hline \multicolumn{7}{|l|}{ Dep. variable (items of GAE) } \\
\hline \multicolumn{7}{|l|}{ GAE3. Ethics in personal decisions $(n=464)$} \\
\hline B & -0.084 & $-0.169 * *$ & $-0.034 *$ & 0.047 & 0.006 & -0.014 \\
\hline SBE & 0.065 & 0.055 & 0.015 & 0.067 & 0.023 & 0.015 \\
\hline $\mathrm{R} 2$ & 0.003 & \multirow{2}{*}{\multicolumn{2}{|c|}{$\begin{array}{c}0.035 \\
5.982 * *\end{array}$}} & \multicolumn{2}{|c|}{0.036} & 0.037 \\
\hline $\mathrm{F}$ & 1.682 & & & & & $3.211 * *$ \\
\hline \multicolumn{7}{|l|}{ GAE4. Ethics in workplace decisions $(n=452)$} \\
\hline B & $-0.175^{*}$ & $-0.242 * *$ & $-0.049 * *$ & 0.056 & -0.036 & $-0.033 *$ \\
\hline SBE & 0.069 & 0.057 & 0.016 & 0.071 & 0.025 & 0.016 \\
\hline $\mathrm{R} 2$ & 0.013 & 0.062 & & & & 0.076 \\
\hline $\mathrm{F}$ & $6.441 *$ & \multicolumn{2}{|c|}{$10.695^{* *}$} & \multicolumn{2}{|c|}{$7.026 * *$} & $6.624 * *$ \\
\hline
\end{tabular}

Note. ${ }^{* *} p<0.01 ;{ }^{*} p<0.05$; B: non-standardized. Ethics/CSR course: $-1=$ students who have not taken a business ethics/CSR course; $+1=$ students who have taken a business ethics/CSR course. Gender: $-1=$ male; $+1=$ female. Age: continuous variable. Dependent variable (items GAE1-OAE7): Likert-type scale (1. Important 7. Unimportant).

Table 4. Hierarchical regression for objectives of accounting education.

\begin{tabular}{|c|c|c|c|c|c|c|}
\hline \multirow[b]{2}{*}{ Independent/Moderating Variables } & \multirow{2}{*}{$\frac{\text { Step1 }}{\text { Ethics/CSR Course }}$} & \multicolumn{2}{|c|}{ Step2 } & \multicolumn{2}{|c|}{ Step 3} & \multirow{2}{*}{$\frac{\text { Step } 4}{\text { Course }^{*} \text { Gender }{ }^{*} \text { Age }}$} \\
\hline & & Gender & Age & Course ${ }^{*}$ Gender & Course * Age & \\
\hline \multicolumn{7}{|l|}{ Dep. variable (items of OAE) } \\
\hline \multicolumn{7}{|c|}{ OAE1. Relating accounting education to moral issues $(n=462)$} \\
\hline B & $-0.161^{*}$ & $-0.147^{*}$ & $-0.061 * *$ & -0.064 & 0.007 & -0.025 \\
\hline SBE & 0.076 & 0.065 & 0.018 & 0.078 & 0.027 & 0.018 \\
\hline R2 & 0.009 & \multicolumn{2}{|c|}{0.039} & \multicolumn{2}{|c|}{0.041} & 0.044 \\
\hline $\mathrm{F}$ & $4.482 *$ & \multicolumn{2}{|c|}{$6.777^{* *}$} & \multicolumn{2}{|c|}{$4.216^{* *}$} & 3.839 ** \\
\hline \multicolumn{7}{|c|}{ OAE2. Recognizing ethical implications in accounting issues $(n=463)$} \\
\hline B & -0.059 & $-0.187^{* *}$ & $-0.065^{* *}$ & -0.011 & 0.006 & $-0.035 *$ \\
\hline SBE & 0.070 & 0.059 & 0.016 & 0.072 & 0.025 & 0.016 \\
\hline $\mathrm{R} 2$ & 0.001 & \multirow{2}{*}{\multicolumn{2}{|c|}{$\begin{array}{c}0.046 \\
8.083 * *\end{array}$}} & \multicolumn{2}{|c|}{0.047} & 0.055 \\
\hline $\mathrm{F}$ & 0.713 & & & & & $4.827^{* *}$ \\
\hline
\end{tabular}


Table 4. Cont

\begin{tabular}{|c|c|c|c|c|c|c|}
\hline \multirow[b]{2}{*}{ Independent/Moderating Variables } & \multirow{2}{*}{$\begin{array}{c}\text { Step1 } \\
\text { Ethics/CSR Course }\end{array}$} & \multicolumn{2}{|c|}{ Step2 } & \multicolumn{2}{|c|}{ Step 3} & \multirow{2}{*}{$\begin{array}{c}\text { Step } 4 \\
\text { Course }{ }^{*} \text { Gender } * \text { Age * }\end{array}$} \\
\hline & & Gender & Age & Course * Gender & Course * Age & \\
\hline \multicolumn{7}{|l|}{ Dep. variable (items of OAE) } \\
\hline \multicolumn{7}{|c|}{ OAE3. Developing a "sense of moral obligation" $(n=464)$} \\
\hline B & -0.070 & -0.172 ** & $-0.045^{* *}$ & -0.007 & -0.005 & -0.025 \\
\hline SBE & 0.070 & 0.060 & 0.016 & 0.073 & 0.025 & 0.016 \\
\hline R2 & 0.002 & \multicolumn{2}{|c|}{0.030} & \multicolumn{2}{|c|}{0.030} & 0.034 \\
\hline $\mathrm{F}$ & 0.993 & \multicolumn{2}{|c|}{$5.102 * *$} & \multicolumn{2}{|c|}{$3.058^{* *}$} & $2.947^{* *}$ \\
\hline \multicolumn{7}{|c|}{ OAE4. Developing conflict-tackling abilities $(n=463)$} \\
\hline B 1 & -0.105 & $-0.225 * *$ & -0.038 & 0.043 & -0.006 & -0.027 \\
\hline SBE & 0.070 & 0.059 & 0.016 & 0.072 & 0.025 & 0.016 \\
\hline $\mathrm{R} 2$ & 0.005 & \multicolumn{2}{|c|}{0.040} & \multicolumn{2}{|c|}{0.041} & 0.046 \\
\hline $\mathrm{F}$ & 2.268 & \multicolumn{2}{|c|}{$6.907 * *$} & \multicolumn{2}{|c|}{$4.224^{* *}$} & $4.003 * *$ \\
\hline \multicolumn{7}{|c|}{ OAE5. Learning to deal with uncertainties $(n=462)$} \\
\hline B & 0.007 & -0.170 ** & -0.025 & -0.121 & -0.035 & -0.007 \\
\hline SBE & 0.067 & 0.057 & 0.016 & 0.070 & 0.024 & 0.016 \\
\hline R2 & 0.000 & \multicolumn{2}{|c|}{0.021} & \multicolumn{2}{|c|}{0.030} & 0.030 \\
\hline $\mathrm{F}$ & 0.010 & \multicolumn{2}{|c|}{3.511 * } & \multicolumn{2}{|c|}{$3.045 *$} & $2.568^{*}$ \\
\hline \multicolumn{7}{|c|}{ OAE6. Fostering change in ethical behaviour $(n=463)$} \\
\hline B & $-0.187^{* *}$ & $-0.302 * *$ & $-0.074 * *$ & -0.016 & -0.006 & -0.030 \\
\hline SBE & 0.068 & 0.056 & 0.015 & 0.068 & 0.023 & 0.015 \\
\hline R2 & 0.015 & \multicolumn{2}{|c|}{0.100} & \multicolumn{2}{|c|}{0.101} & 0.107 \\
\hline $\mathrm{F}$ & $7.569^{* *}$ & \multicolumn{2}{|c|}{$18.554^{* *}$} & \multicolumn{2}{|c|}{$11.113^{* *}$} & $9.948^{* *}$ \\
\hline \multicolumn{7}{|c|}{ OAE7. Understanding ethical aspects of accounting ethics $(n=463)$} \\
\hline B & 0.022 & $-0.221 * *$ & $-0.048 * *$ & -0.010 & -0.011 & -0.013 \\
\hline SBE & 0.074 & 0.063 & 0.017 & 0.076 & 0.026 & 0.017 \\
\hline $\mathrm{R} 2$ & 0.000 & \multicolumn{2}{|c|}{0.036} & \multicolumn{2}{|c|}{0.036} & 0.037 \\
\hline $\mathrm{F}$ & 0.087 & \multicolumn{2}{|c|}{$6.161 * *$} & \multicolumn{2}{|c|}{$3.718^{* *}$} & $3.190^{* *}$ \\
\hline
\end{tabular}

Note. ${ }^{* *} p<0.01 ;{ }^{*} p<0.05$; B: non-standardized. Ethics/CSR courses: $-1=$ students who have not taken a business ethics/CSR course; $+1=$ students who have taken a business ethics/CSR course. Gender: $-1=$ male; $+1=$ female. Age: continuous variable. Dependent variable (items GAE1-OAE7): Likert-type scale (1. Important ... 7. Unimportant). 
In H1, we proposed that taking an ethics/CSR course positively impacts management students' ethical awareness. According to step 1 of the hierarchical regression analysis, although all GAE (Table 3) and most OAE (Table 4) show relations in line with the hypothesized direction, only half (two out of four) of the GAE aspects and two (out of seven) OAE aspects indicate significant relations. These outcomes lead to partial acceptance of H1. Specifically, we can state that taking ethics/CSR courses positively impacts some aspects of management students' ethical awareness, namely the perception of importance of ethics in business courses (GAE2) and in workplace decisions (GAE4), relating accounting education to moral issues (OAE1), and (the most significant relation, $p<0.01$ ) fostering change in ethical behaviour (OAE6). These mixed results are generally in line with the outcomes of extant research (e.g., [14,32,38-42]). Step 2 of Table 3 (GAE) and Table 4 (OAE) also show results in line with the extant literature on the impact of gender and age on students' ethical awareness, and are thus generally consistent with our assumptions on these relations. We can then confidently proceed with the analysis of moderation effects from gender and age.

As for the two-way interactions, $\mathrm{H} 2$ and $\mathrm{H} 3$ state that the positive influence of exposure to business ethics/CSR course on business students' ethical awareness is positively moderated by the fact of being a female (H2) or an older (H3) student. Our results do not support any of these hypotheses, since none of GAE and OAE items show significant relations with either gender or age. This outcome deserves further thought and poses theoretical and empirical challenges.

Finally, in H4, we proposed that the positive influence of taking business ethics/CSR courses on management students' ethical awareness is positively moderated simultaneously by the facts of being both female and an older student. This hypothesis is partially accepted, just for two out of the 11 items measuring students' ethical awareness. On the one hand, it is accepted for one (out of four) of the GAE items, namely importance of ethics in workplace decisions (GAE4). In addition, it is also accepted for one (out of seven) OAE items, namely recognizing issues in accounting that have ethical implications (OAE2). Relevant implications and challenges also emerge from these (mixed) results, as is commented in the next section.

\section{Discussion}

This investigation adds timely results to the business ethics education literature. Specifically, it sheds further light on the influence of ethics teaching on the ethical perceptions and behaviour of management students. Our results vary depending on the type of ethical aspect considered. The two GAE items that have been significantly influenced by ethics/CSR courses (H1) are, precisely, the importance of ethics in business courses (GAE2) and in workplace decisions (GAE4). In turn, the importance of ethics in workplace decisions seems a relevant predictor of future ethical behaviour of management (and particularly accounting) professionals. These dynamics are consistent with the link that prior research has found between students' unethical academic behaviour and unethical workplace beliefs [61]. In contrast, the perception of the importance of ethics in the business community and in personal decisions (which did not appear to be significant) are related to observations and values that seem rather indirectly connected to whether and how business ethics is taught. Furthermore, the most significant aspect of students' ethical awareness was the OAE, labelled as the importance of fostering change in ethical behaviour (OAE6, $p<0.01)$. This seems to be the broadest, most straightforward, and easy to comprehend aspect among all OAE items.

Hypotheses concerning separate $(\mathrm{H} 2$ and $\mathrm{H} 3)$ and combined $(\mathrm{H} 4)$ moderating effects from gender and age on the influence of an ethics/CSR course on ethical awareness performed rather poorly. However, detailed analysis of some nuances related to $\mathrm{H} 4$ findings offer relevant and though-provoking reflections. Let us focus on the two aspects (one GAE out of four, and one OAE out of seven) of ethical awareness that were significantly impacted by the three-way interaction among ethics/CSR course, gender, and age: importance of ethics in workplace decisions (GAE4), and recognizing ethical implications in accounting issues (OAE2). 
The importance of ethics in workplace decisions (GAE4) is the specific aspect of students' ethical awareness that seems to predict most accurately the (un)ethical behaviour of future management (and particularly accounting) professionals. The other aspect of ethical awareness that was significantly affected by the three-way (ethics/CSR course, gender, and age) interaction was the importance of recognizing issues in accounting that have ethical implications (OAE2). This is the most workplace-related of all (seven) OAE items, and hence it may also have a strong predictive power on future professional (un)ethical behaviour. In other words, the joint moderation effect of gender (i.e., being female) and age (i.e., being older) turn the recognition of accounting ethical implications into a significant consequence of taking ethics/CSR courses. Extant research evidence is in line with these ideas, in the sense that standardized ethics training seems to have a more effective impact on women, whereas men would need more customized methods [62].

The above considerations are consistent with the traditional perspectives on learning styles, according to which teaching methods should fit the learning style of the student-as the most effective way of boosting academic success [63]. Research to date has evidenced differences in individual learning style preferences. Genetic loading, individual life experiences, and different current demands jointly call for dissimilar personal learning styles [64]. Indeed, learning is not limited to the classroom; it involves experience-sharing and socialization processes through which students collaborate and learn from each other $[65,66]$. According to the Social Learning Theory [67], individuals observe and imitate others' behaviour (including class mates). Hence, structuring teaching around demographically diverse classroom workgroups seems an interesting starting point to optimize learning-as mixed-gender approaches have suggested (e.g., [68]).

Let us deepen now into the analysis of the two above aspects of students' ethical awareness that are significantly affected by the three-way interaction among ethics/CSR course, gender, and age (in the context of H4). As shown in Figure 2, without an ethics/CSR course, female students perceive ethics in workplace decisions as more important than their male counterparts. Besides, regardless of taking an ethics/CSR course, older male students perceive ethics in workplace decisions as more important than their younger counterparts. If male students have taken an ethics/CSR course, regardless of whether they are younger or older, they consistently improve their awareness on the importance of ethics in workplace decisions, as older female students also do. However, among younger students, ethics/CSR courses have a weaker impact on women than on men. What is more, whereas younger male students' ethical awareness on GAE4 seems to be positively affected by business ethics education, their female counterparts appear to be negatively affected (i.e., the more ethical training young female students receive, the lower their ethical awareness is). Hence, further inquiry should progress towards better understanding of why younger female students appear to react more poorly to business ethics/CSR courses than their male counterparts.

Moreover, as shown in Figure 3, without an ethics/CSR course, recognizing accounting issues with ethical implications is perceived as more important by female students than by their male counterparts. An exception to this general situation is the case of older male students who have not received ethics training vs. their female counterparts. Under these circumstances, both groups seem to show a similar (intermediate) degree of awareness towards the importance of recognizing accounting issues with ethical implications. Further research is needed to ascertain why female older students do not show a higher innate ethical awareness on the above aspects than their male counterparts. In any case, and regardless of having taken an ethics/CSR course or not, older students (both male and female) perceive ethics as more important than younger students. Nevertheless, when an ethics/CSR course has been taken, and among younger students, men show a better response than women. In fact, young female students seem to react negatively to ethics training. These findings, which seem to contradict some aspects of $\mathrm{H} 4$, pose relevant questions for future research. The existence of different learning styles linked to students' diverse demographic characteristics—as suggested by extant research regarding e.g., gender [68,69]—might help explain these results. However, many questions remain open and deserve further inquiry. 


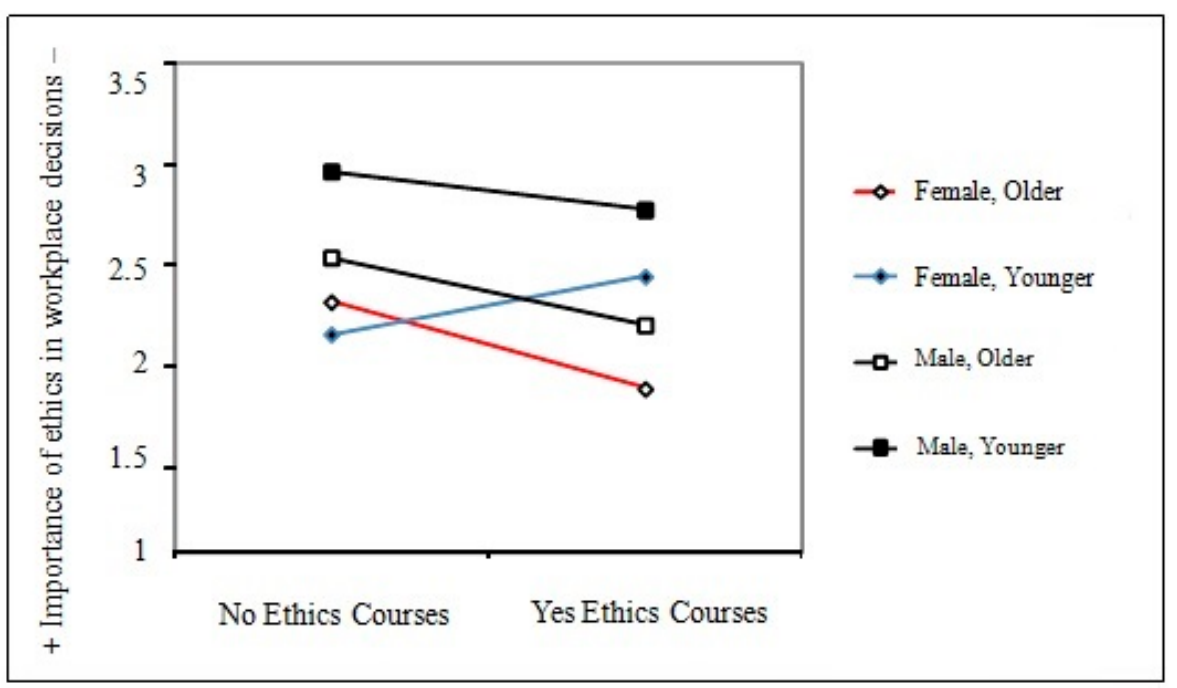

Figure 2. Three-way interactions among business ethics/CSR courses, gender and age on business students' awareness of the importance of ethics in workplace decisions.

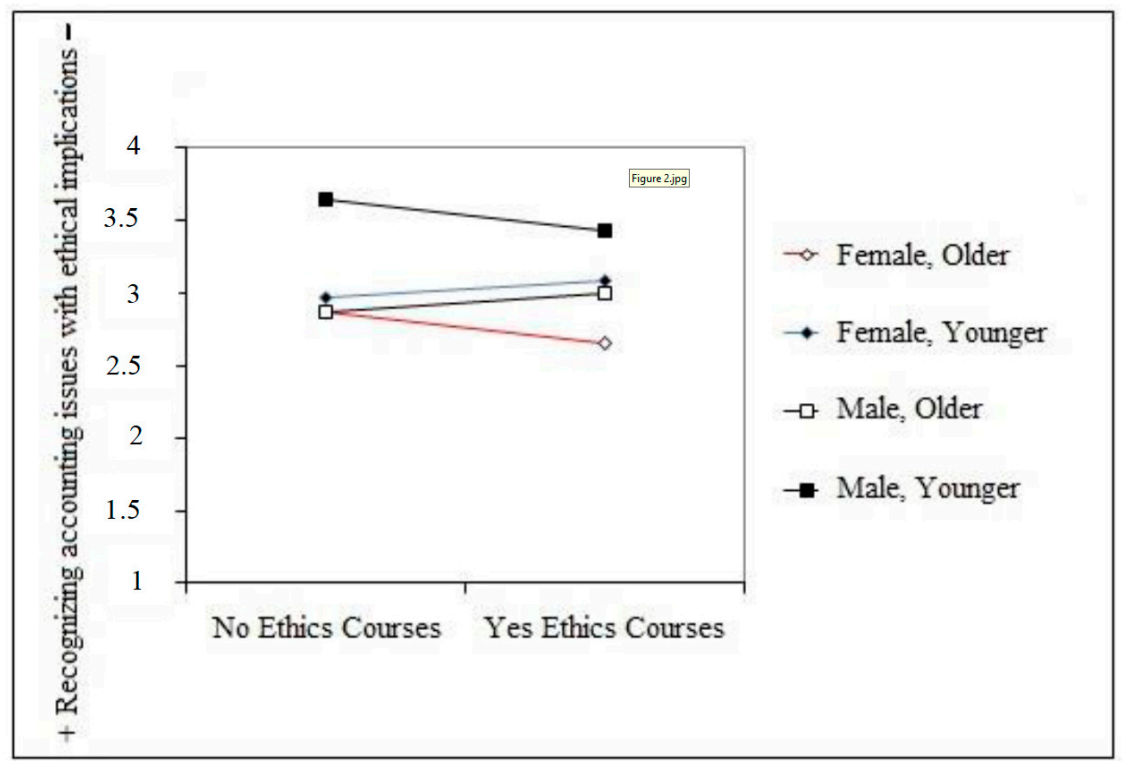

Figure 3. Three-way interactions among business ethics/CSR courses, gender and age on business students' awareness of the importance of recognizing issues in accounting that have ethical implications.

\section{Conclusions}

Our investigation contributes to a better understanding of the role that business ethics education plays in (triple bottom line inspired) sustainability goals. In this sense, our study supports the need of extending the introduction of ethics/CSR courses in official university curricula in ethics-unfriendly environments. Responding to claims on the important role of higher education in shaping future graduates' professional responsibility, our investigation expands previous enquiry and contributes to the state-of-the-art enquiry on students' (accounting) ethical awareness in connection with ethics/CSR courses taken at university. More specifically, our investigation explores how students' ethical awareness can potentially predict future (un)ethical behaviour in the workplace, especially in the accounting profession. Data collection procedures already applied in prior research (e.g., [32]) have been now further validated in the Spanish (relatively ethics-unfriendly) context. Our study is arguably among the first to analyze different types of interactions between several variables (ethics/CSR courses, 
gender, age) that potentially impact the effectiveness of ethics teaching, understood as improved business students' (accounting) ethical awareness.

Practical implications can be derived from our study. Business schools are encouraged to re-examine the teaching of business ethics, and hence they should re-assess their role in training ethically minded, honest, and trustworthy future management professionals. Particularly, customizing ethics training to different students' needs and adapting learning materials according to students learning styles help students learn more easily and effectively [62,70]. Finally, another way to increase students' effectiveness is to encourage them to learn from each other-e.g., through mixed-gender groups [68].

Deepening into the above considerations, may we note that our findings are consistent with prior research, insofar characteristics of the students themselves influence the effectiveness of instruction of ethics courses [71]. Notably, student's gender influences course effectiveness: men tend to have a lower start level of ethical awareness; they can be expected to have larger gains from these courses than women [71]. In this sense, men and women react to situations differently due to socialization. According to this perspective, if families, societies and, in this case, also business schools, contribute to socialize both genders similarly, men and women should be aligned in their ethical approach [72], so the benefits of ethics/CSR courses might be more beneficial to students of both genders in a more balanced way. Besides, as older students show a greater maturity with regard to emotional self-regulation and social interactions [73], we would recommend instructors of ethics/CSR courses to focus on gaining them as allies in course development and class dynamics, so as to win the commitment of their younger counterparts.

More specific practical implications suggest the delivery of ethics/CSR instructional content using multiple expert trainers, integrated cases, and practice activities that encourage active trainee participation, thus benefiting student learning, ideas consistent with the extant literature, as e.g., Watts et al. [71] found out in their meta-analysis of ethics programmes in science disciplines. Moreover, regarding the importance of students' active participation in business ethics/CSR programmes, courses should have a clear focus and avoid dispersion, including a diversity of relatively short and frequent-both individual and group-based-practice activities. These ideas are consistent with the suggestions by Medeiros et al. [74], who state that business ethics courses should narrow their focus and choose just between one and three main goals: in general, providing short, focused training may be the most beneficial approach for improving ethical decision making and ethical behaviour. However, caution is advised regarding business ethics instruction programme development, as participants with prior exposure to instruction in ethics may not show the same gains as those who are exposed to such material for the first time [71]. Last, but not least, it is worthwhile to stress the importance of considering three interdependent levels of programme design and implementation, namely institutional, curricular, and instrumental/methodological levels, thus building a multi-level framework, which is also integrative of ethics, CSR and sustainability in management education [2].

This investigation has some limitations. The nature of the sample (business students of a single Spanish university) constrains the potential of results generalization. Another limitation may be connected to social desirability bias [75], particularly prevalent in research on ethical issues [76,77]. However, in our study, we have tried to reduce the risk of this bias by focusing on aspects of actual behaviour (notably, effectively enrolling into ethics/CSR courses) and not merely on intentions (desire to enrol). Some of these limitations are further reduced by the large simple size and the relatively homogeneous research subjects (all of them university students), although at the same time emphasizing in our analysis demographic differences among students (in terms of gender and age), so the differences between different student types provide the most revealing findings, not the absolute, aggregated results.

Our study also opens up opportunities for further research. For instance, it could be interesting to explore how business ethics/CSR courses might eventually influence the potential development of sustainability practices by future managers (current students). Extant literature offers some basis 
for this type of inquiry, such as Haggard and Eimer [78], who examined the connections between intention and brain processes, concluding that conscious awareness of intention is linked to the selection of a specific action, and not to the earliest initiation of action processes. Since business ethics/CSR courses influence ethical awareness, the future choice, development and implementation of sustainability practices may be facilitated. Moreover, cross-cultural approaches can be applied in the future: wider samples including different countries and student diversity (including cultural aspects such as nationality, ethnicity, religion, etc.) may help achieve a better understanding of how cultural differences can potentially influence management students' perceptions of business ethics/CSR (courses), and also the effectiveness of such courses. Finally, future investigations could apply more complex data analysis methods, such as structural equation modelling, which would allow to obtain a richer picture of the links among the different variables involved.

Author Contributions: G.T.-C. conceived, designed and performed the experiments; G.T.-C., E.S.-M. and V.O. wrote the literature review section and set the hypotheses. G.T.-C., E.S.-M. and V.O. analyzed the data; E.S.-M. contributed, designed and passed out the questionnaire and managed the data; V.O. wrote the paper.

Funding: This research received no external funding

Acknowledgments: The authors would like to thank Helena-Maria Bollas-Araya for her support in reviewing the formal aspects of the manuscript.

Conflicts of Interest: The authors declare no conflict of interest.

\section{Appendix A}

Questionnaire items

Section 1. General aspects of ethics (GAE). How important is ... ?

GAE1. Ethics in the business community.

GAE2. Ethics in business courses.

GAE3. Ethics in your personal decisions.

GAE4. Ethics in your decisions in the workplace.

Section 2. Objectives of accounting ethics education (OAE). How important is ... ?

OAE1. Relating accounting education to moral issues.

OAE2. Recognizing issues in accounting that have ethical implications.

OAE3. Developing "a sense of moral obligation" or responsibility.

OAE4. Developing the abilities needed to deal with ethical conflicts or dilemmas.

OAE5. Learning to deal with the uncertainties of the accounting profession.

OAE6. Fostering change in ethical behaviour.

OAE7. Appreciating and understanding the history and composition of all aspects of accounting ethics and their relationship to the general field of ethics.

\section{References}

1. Pauw, J.B.-D.; Gericke, N.; Olsson, D.; Berglund, T. The Effectiveness of Education for Sustainable Development. Sustainability 2015, 7, 15693-15717. [CrossRef]

2. Setó-Pamies, D.; Papaoikonomou, E. A Multi-level Perspective for the Integration of Ethics, Corporate Social Responsibility and Sustainability (ECSRS) in Management Education. J. Bus. Ethics 2015. [CrossRef]

3. Bergman, M.M.; Bergman, Z; Berger, L. An Empirical Exploration, Typology, and Definition of Corporate Sustainability. Sustainability 2017, 9, 753. [CrossRef]

4. Burford, G.; Hoover, E.; Velasco, I.; Janoušková, S.; Jimenez, A.; Piggot, G.; Podger, D.; Harder, M.K. Bringing the 'missing pillar' into Sustainable Development Goals: Towards intersubjective values-based indicators. Sustainability 2013, 5, 3035-3059. [CrossRef]

5. Burford, G.; Hoover, E.; Stapleton, L.; Harder, M.K. An Unexpected Means of Embedding Ethics in Organizations: Preliminary Findings from Values-Based Evaluations. Sustainability 2016, 8, 612. [CrossRef] 
6. Bampton, R.; Cowton, C.J. The teaching of ethics in management accounting: Progress and prospects. Bus. Ethics Eur. Rev. 2002, 11, 52-61. [CrossRef]

7. Biedenweg, K.; Monroe, M.C.; Oxarart, A. The importance of teaching ethics of sustainability. Int. J. Sust. Higher Educ. 2013, 14, 6-14. [CrossRef]

8. Harris, H. Promoting ethical reflection in the teaching of business ethics. Bus. Ethics Eur. Rev. 2008, 17, 379-390. [CrossRef]

9. Larrán Jorge, M.; Andrades Peña, F.J. Determinants of corporate social responsibility and business ethics education in Spanish universities. Bus. Ethics Eur. Rev. 2014, 23, 139-153. [CrossRef]

10. Loeb, S.E. Teaching students accounting ethics: Some crucial issues. Issues Account. Educ. 1988, 3, 316-329.

11. Maclagan, P. Conflicting obligations, moral dilemmas and the development of judgement through business ethics education. Bus. Ethics Eur. Rev. 2012, 21, 183-197. [CrossRef]

12. Maclagan, P.; Campbell, T. Focusing on individuals' ethical judgement in corporate social responsibility curricula. Bus. Ethics Eur. Rev. 2011, 20, 392-404. [CrossRef]

13. Marnburg, E. Educational impacts on academic business practitioner's moral reasoning and behaviour: Effects of short courses in ethics or philosophy. Bus. Ethics Eur. Rev. 2003, 12, 403-413. [CrossRef]

14. Tormo-Carbó, G.; Seguí-Mas, E.; Oltra, V. Accounting ethics in unfriendly environments: The educational challenge. J. Bus. Ethics 2014. [CrossRef]

15. Bampton, R.; Cowton, C.J. Taking stock of accounting ethics scholarship: A review of the journal literature. J. Bus. Ethics 2013, 114, 549-563. [CrossRef]

16. Lee, B.K.; Sohn, S.Y. A Credit Scoring Model for SMEs Based on Accounting Ethics. Sustainability 2017, 9, 15-88. [CrossRef]

17. Ceulemans, K.; Lozano, R.; Alonso-Almeida, M.M. Sustainability reporting in higher education: Interconnecting the Reporting Process and Organisational Change Management for Sustainability. Sustainability 2015, 7, 8881-8903. [CrossRef]

18. Sammalisto, K.; Sundström, A.; von Haartman, R.; Holm, T.; Yao, Z. Learning about Sustainability-What Influences Students' Self-Perceived Sustainability Actions after Undergraduate Education? Sustainability 2016, 8, 510. [CrossRef]

19. Boni, A.; Lozano, J.F. The generic competences: An opportunity for ethical learning in the European convergence in higher education. High. Educ. 2007, 54, 819-831. [CrossRef]

20. Sánchez, R.G.; Bolívar, M.P.R.; Hernández, A.M.L. Are Australian Universities Making Good Use of ICT for CSR Reporting? Sustainability 2015, 7, 14895-14916. [CrossRef]

21. Uysal, O.O. Business ethics research with an accounting focus: A bibliometric analysis from 1988 to 2007. J. Bus. Ethics 2010, 93, 137-160. [CrossRef]

22. CRUE. La Universidad Española en Cifras 2015/2016. Available online: http://www.crue.org/ Documentos\%20compartidos/Publicaciones/Universidad\%20Espa\%C3\%B1ola\%20en\%20cifras/UEC_ Digital_WEB.pdf (accessed on 18 May 2018).

23. Randstad. Ingeniería Industrial, ADE e Informática son las Carreras con Mejores Perspectivas Laborales en España. 2014. Available online: http:/ / www.randstad.es/nosotros/sala-prensa/randstad-17-09-2014 (accessed on 5 May 2015).

24. Setó-Pamies, D.; Domingo-Vernis, M.; Rabassa-Figueras, N. Corporate social responsibility in management education: Current status in Spanish universities. J. Health Organ. Manag. 2011, 17, 604-620. [CrossRef]

25. Garavan, T.N.; McGuire, D. Human resource development and society: Human resource development's role in embedding corporate social responsibility, sustainability, and ethics in organizations. Adv. Dev. Hum. Resour. 2010, 12, 487-507. [CrossRef]

26. Donaldson, T.; Dunfee, T.W. Towards a unified conception of business ethics: Integrative social contracts theory. Acad. Manag. Rev. 1994, 19, 252-284. [CrossRef]

27. BBC. Rato and Other Bankia Officials Face Fraud Probe. BBC News, 4 July 2012. Available online: http: / / www.bbc.co.uk/news/business-18705836 (accessed on 24 April 2015).

28. Kassam, A. Spanish authorities arrest 51 top figures in anti-corruption sweep. The Guardian, 27 October 2014. Available online: http:/ / www.theguardian.com/world/2014/oct/27/spanish-authorities-arrest-51-anticorruption-sweep (accessed on 5 May 2015).

29. Gallego-Alvarez, I. Analysis of social information as a measure of the ethical behaviour of Spanish firms. Manag. Decis. 2008, 46, 580-599. [CrossRef] 
30. Dellaportas, S.; Cooper, B.J.; Leung, P. Measuring moral judgement and the implications of cooperative education and rule-based learning. Account. Financ. 2006, 46, 53-70. [CrossRef]

31. Graham, A. The teaching of ethics in undergraduate accounting programmes: The students' perspective. Account. Educ. 2012, 21, 599-613. [CrossRef]

32. Waples, E.P.; Antes, A.L.; Murphy, S.T.; Connelly, S.; Mumford, M.D. A meta-analytic investigation of business ethics instruction. J. Bus. Ethics 2009, 87, 133-151. [CrossRef]

33. Watts, L.L.; Mulhearn, T.J.; Medeiros, K.E.; Steele, L.M.; Connelly, S.; Mumford, M.D. Modeling the instructional effectiveness of responsible conduct of research education: A meta-analytic path-analysis. Ethics Behav. 2017, 27, 632-650. [CrossRef]

34. Loeb, S.E. Active learning: An advantageous yet challenging approach to accounting ethics instruction. J. Bus. Ethics 2015, 127, 221-230. [CrossRef]

35. Adkins, N.; Radtke, R.R. Students' and faculty members' perceptions of the importance of business ethics and accounting ethics education: Is there an expectations gap? J. Bus. Ethics 2004, 51, 279-300. [CrossRef]

36. Bampton, R.; Maclagan, P. Why teach ethics to accounting students? A response to the sceptics. Bus. Ethics Eur. Rev. 2005, 14, 290-300. [CrossRef]

37. Ferguson, J.; Collison, D.; Power, D.; Stevenson, L. Accounting education, socialisation and the ethics of business. Bus. Ethics Eur. Rev. 2011, 20, 12-29. [CrossRef]

38. Neureuther, B.D.; Swicegood, P.; Williams, P. The efficacy of business ethics courses when coupled with a personal belief system. J. Coll. Teach. Learn. 2011, 1, 17-22. [CrossRef]

39. Low, M.; Davey, H.; Hooper, K. Accounting scandals, ethical dilemmas and educational challenges. Crit. Perspect. Accoun. 2008, 19, 222-254. [CrossRef]

40. Dearman, D.; Beard, J. Ethical Issues in Accounting and Economics Experimental Research: Inducing Strategic Misrepresentation. Ethics Behav. 2009, 19, 51-59. [CrossRef]

41. O'Fallon, M.J.; Butterfield, K.D. A review of the empirical ethical decision-making literature: 1996-2003. J. Bus. Ethics 2005, 59, 375-423. [CrossRef]

42. Ritter, B.A. Can business ethics be trained? A study of the ethical decision-making process in business students. J. Bus. Ethics 2006, 68, 153-164. [CrossRef]

43. Nguyen, N.T.; Basuray, M.T.; Smith, W.P.; Kopka, D.; McCulloh, D. Moral issues and gender differences in ethical judgement using Reidenbach and Robin's (1990) multidimensional ethics scale: Implications in teaching of business ethics. J. Bus. Ethics 2008, 77, 417-430. [CrossRef]

44. Eagly, A.H. Sex Differences in Social Behaviour: A Social-Role Interpretation; Erlbaum: Hillsdale, NJ, USA, 1987.

45. Eagly, A.H.; Steffen, V.J. Gender stereotypes stem from the distribution of women and men into social roles. J. Pers. Soc. Psychol. 1984, 46, 735-754. [CrossRef]

46. Pan, Y.; Sparks, J.R. Predictors, consequence, and measurement of ethical judgments: Review and meta-analysis. J. Bus. Res. 2012, 65, 84-91. [CrossRef]

47. Tenbrunsel, A.E.; Smith-Crowe, K. Ethical decision making: Where we've been and where we're going. Acad. Manag. Ann. 2008, 2, 545-607. [CrossRef]

48. Craft, J.L. A review of the empirical ethical decision-making literature: 2004-2011. J. Bus. Ethics 2013, 117, 221-259. [CrossRef]

49. McCabe, A.C.; Ingram, R.; Dato-on, M.C. The business of ethics and gender. J. Bus. Ethics 2006, 64, 101-116. [CrossRef]

50. Eweje, G.; Brunton, M. Ethical perceptions of business students in a New Zealand university: Do gender, age and work experience matter? Bus. Ethics Eur. Rev. 2010, 19, 95-111. [CrossRef]

51. Stedham, Y.; Yamamura, J.H.; Beekun, R.I. Gender differences in business ethics: Justice and relativist perspectives. Bus. Ethics Eur. Rev. 2007, 16, 163-174. [CrossRef]

52. Luthar, H.K.; Karri, R. Exposure to ethics education and the perception of linkage between organizational ethical behaviour and business outcomes. J. Bus. Ethics 2005, 61, 353-368. [CrossRef]

53. Kohlberg, L. Stage and sequence: The cognitive- developmental approach to socialization. In Handbook of Socialization Theory and Research; Goslin, D.A., Ed.; Rand McNally: Chicago, UI, USA, 1969; pp. 347-480.

54. Ede, F.O.; Panigrahi, B.; Stuart, J.; Calcich, S. Ethics in small minority businesses. J. Bus. Ethics 2000, 26, 133-146. [CrossRef]

55. Kish-Gephart, J.J.; Harrison, D.A.; Treviño, L.K. Bad apples, bad cases, and bad barrels: Meta-analytic evidence about sources of unethical decisions at work. J. Appl. Psychol. 2010, 95, 1. [CrossRef] [PubMed] 
56. Peterson, D.; Rhoads, A.; Vaught, B.C. Ethical beliefs of business professionals: A study of gender, age and external factors. J. Bus. Ethics 2001, 31, 225-232. [CrossRef]

57. Callahan, D. Goals in the teaching of ethics. In Ethics Teaching in Higher Education; Callahan, D., Bok, S., Eds.; Plenum Press: New York, NY, USA, 1980; pp. 61-80.

58. Geary, W.; Sims, R. Can Ethics be Learned? Account. Educ. 1994, 3, 3-18. [CrossRef]

59. Hayes, A.F. Introduction to Mediation, Moderation, and Conditional Process Analysis: A Regression-Based Approach; Guilford Press: New York, NY, USA, 2008.

60. Cohen, J.; Cohen, P.; West, S.G.; Aiken, L.S. Applied Multiple Regression/Correlation Analysis for the Behavioral Sciences; Routledge: Mahwah, NJ, USA, 2013.

61. Hsiao, C.H. Impact of ethical and affective variables on cheating: Comparison of undergraduate students with and without jobs. High. Educ. 2015, 69, 55-77. [CrossRef]

62. Herington, C.; Weaven, S. Improving consistency for DIT results using cluster analysis. J. Bus. Ethics 2008, 80, 499-514. [CrossRef]

63. Kolb, D.A.; Boyatzis, R.E.; Mainemelis, C. Experiential learning theory: Previous research and new directions. In Perspectives on Thinking, Learning, and Cognitive Styles; Routledge: Abingdon, UK, 2001; pp. 227-247.

64. Kolb, A.Y.; Kolb, D.A. Learning styles and learning spaces: Enhancing experiential learning in higher education. Acad. Manag. Learn. Educ. 2005, 4, 193-212. [CrossRef]

65. Lawter, L.; Rua, T.; Guo, C. The interaction between learning styles, ethics education, and ethical climate. J. Manag. Dev. 2014, 33, 580-593. [CrossRef]

66. Passarelli, A.M.; Kolb, D.A. The Learning Way: Learning from Experience as the Path to Lifelong. In The Oxford Handbook of Lifelong Learning; Oxford University Press: Oxford, UK, 2011; p. 70.

67. Bandura, A. Social Learning Theory; Prentice-Hall: Englewood Cliffs, NJ, USA, 1977.

68. Lie, L.Y.; Angelique, L.; Cheong, E. How do male and female students approach learning at NUS. CDTL Brief 2004, 7, 1-3.

69. Baxter Magolda, M.B. Learning and gender: Complexity and possibility. High. Educ. 1998, 35, 351-355. [CrossRef]

70. Prabhakar, V.; Swapna, B. Influence of learning styles. Int. J. Learn. 2009, 16, 169-184.

71. Watts, L.L.; Medeiros, K.E.; Mulhearn, T.J.; Steele, L.M.; Connelly, S.; Mumford, M.D. Are ethics training programs improving? A meta-analytic review of past and present ethics instruction in the sciences. Ethics Behav. 2017, 27, 351-384. [CrossRef]

72. Roxas, M.L.; Stoneback, J.Y. The Importance of gender Across Cultures in Ethical Decision-making. J. Bus. Ethics 2004, 50, 149-165. [CrossRef]

73. Decety, J.; Michalska, K.J.; Kinzler, K.D. The developmental neuroscience of moral sensitivity. Emot. Rev. 2011, 3, 305-307. [CrossRef]

74. Medeiros, K.E.; Watts, L.L.; Mulhearn, T.J.; Steele, L.M.; Mumford, M.D.; Connelly, S. What is working, what is not, and what we need to know: A meta-analytic review of business ethics instruction. J. Acad. Ethics 2017, 15, 245-275. [CrossRef]

75. Chung, J.; Monroe, G. Exploring social desirability bias. J. Bus. Ethics 2003, 44, 291-302. [CrossRef]

76. Carrigan, M.; Atalla, A. The myth of the ethical consumer-Do ethics matter in purchase behaviour? J. Consum. Mark. 2001, 18, 560-578. [CrossRef]

77. Podsakoff, P.M.; Organ, D.W. Self-reports in organizational research: Problems and prospects. J. Manag. 1986, 12, 531-544. [CrossRef]

78. Haggard, P.; Eimer, M. On the relation between brain potentials and the awareness of voluntary movements. Exp. Brain. Res. 1999, 126, 128-133. [CrossRef] [PubMed]

(C) 2018 by the authors. Licensee MDPI, Basel, Switzerland. This article is an open access article distributed under the terms and conditions of the Creative Commons Attribution (CC BY) license (http:/ / creativecommons.org/licenses/by/4.0/). 